\title{
An investigation of farm restructuring and sustainable land use - Tutira region, northern Hawke's Bay
}

\section{I.C. Brown', R.D. Black'} and J.M. King ${ }^{2}$

'Hawke's Bay Catchment Board, Napier 'MAFTech, Hastings

ABSTRACT The severity of permanent damage caused by Cyclone Bola to an estimated 65000 ha in northern Hawke's Bay is of sufficient magnitude to necessitate complete changes in land use over that region as a whole. Traditional responses to this problem have included a range of incentives which have been principally designed to ensure the continuation of the existing pastoral use. Recent studies have emphasised the need to rationalise land use on the basis of long term sustainability. The costs of facilitating and permanently establishing this change in land use will be high, and an appropriate sponsor must be found, as market forces and commercial enterprise alone will have insufficient incentive to effect the changes.

Keywords sustainable land use, farm restructuring, Hawke's Bay

\section{INTRODUCTION}

Northern Hawke's Bay has been badly affected by severe storms over a number of years. Cyclone Bola, in March 1988, was the most recent example. Damage included widespread erosion, high stock losses and destruction of communication, road and rail links.

Storm damage has tended to be addressed on the basis of short term solutions, such as Government grants to assist farmers and local authorities to repair damage and to recover at least some of the financial loss. After Bola, however, it was recognised that these short term solutions do little to resolve the major problem of land management practices that are non-sustainable in the long term.

The Hawke's Bay Catchment Board has identified some 65000 ha of hill country, north of Napier, where achieving sustainable land use is a major problem. Given the extent of this area, however, it is recognised that sustainable land use will be achieved only as part of an overall farm restructuring package.

This paper outlines the results of the Tutira Landuse Study and suggests a course of action for achieving effective farm restructuring and sustainable land use.

\section{A NEED FOR CHANGE}

In northern Hawke's Bay the need for farm restructuring stems from two basic causes:

(i) Financial pressure because costs of debt servicing are too high relative to the level of farm income;

(ii) Non-sustainable current land use - for reasons of erosion and lack of economic viability.

Many regions in New Zealand, particularly those which have experienced prolonged drought conditions, are facing this situation, at least in part.

One solution to the problem in not-them Hawke's Bay, proposed by the Hawke's Bay Catchment Board, and supported in a joint project with MAF and Federated Farmers, is to change the patterns of land use and land ownership so that the easier country is kept in pastoral use and the steeper slopes are put into some form of forestry or reserve.

\section{THE KAHIKA EXAMPLE}

A 2018 ha study block (Kahika Block) within the greater 65000 ha study area was chosen to test the concepts of farm restructuring and sustainable land use.

The Kahika study area is situated adjacent to Lake Tutira, approximately $40 \mathrm{~km}$ north of Napier (Figure 1). The block, formerly a land settlement unit which was settled in the mid-1 $960 \mathrm{~s}$, is currently owned as seven individually run properties with separate legal titles.

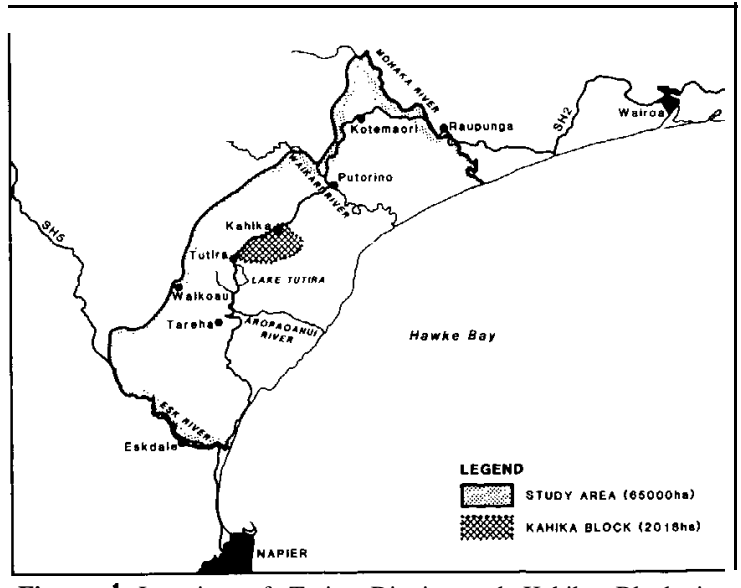

Figure 1 Location of Tutira District and Kahika Block in northern Hawke's Bay. 
The area comprises predominantly moderate (2025 ") to very steep (35") hill country formed on tertiary sediments (Haywick et al.1989), overlain with deposits of loess and rhyolitic tephra. On steeper slopes these deposits have been removed by erosion. The area has been badly affected by severe storms over a number of years (Guthrie-Smith 1953). The latest of these was Cyclone Bola in March 1988. During Cyclone Bola up to $700 \mathrm{~mm}$ of rainfall fell within this area over a 72-hour period (McBryde D. pers. comm.). This resulted in bare ground percentages, due to erosion, of up to $20 \%$ on some farms and up to $50 \%$ on some individual slopes (Trustrum N. pers. comm.).

The Kahika study area was mapped using the Land Use Capability (LUC) System. (Ministry of Works \& Development1974.) To each class mapped was attached a preferred land use, based on long term physical sustainability.

Physical sustainable land use, defmed as 'a land use which does not lead to the physical degrade of the land resource', was determined through the combination of an historical analysis of aerial photographs and the extrapolation of erosion pasture productivity data obtained from elsewhere within the northern Hawke's Bay district. (Douglas et al. 1986). The latter data clearly demonstrated that erosion can result in immediate and often dramatic reductions in pasture production on steep hill country. The extent of this reduction was emphasised in an extension of the original trials which concluded that since bush removal approximately 150 years ago, and under various pastoral farming regimes, potential productivity on steep hill country has declined $30 \%$ and on moderate hill country $15 \%$ (Trustrum pers. con-m.).

A map giving the preferred land use, for each LUC class, within the Kahika block, was overlaid onto a base map which included existing roads, farm boundaries and paddock boundaries. Using this map and after consideration of practical aspects, such as optimum size and workability of pastoral units and forestry constraints, it was recommended that the existing seven farms be consolidated into four units, with the land use being composed as shown in Table 1.

Table 1 Consolidated unit areas Kahika Block

\begin{tabular}{|c|c|c|c|c|}
\hline & $\begin{array}{l}\text { Pastoral } \\
\text { area (ha) }\end{array}$ & $\begin{array}{l}\text { Agroforestry } \\
\text { area (ha) }\end{array}$ & $\begin{array}{l}\text { Woodlot } \\
\text { area (ha) }\end{array}$ & $\begin{array}{l}\text { Total } \\
\text { (ha) }\end{array}$ \\
\hline Farm No. (1) & 240 & 175 & - & 415 \\
\hline Farm No. (2) & 258 & 261 & 18 & 537 \\
\hline Lifestyle Unit & 60 & 65 & - & 125 \\
\hline Forestry Block & & & 891 & 891 \\
\hline Reserve & & & -50 & \\
\hline
\end{tabular}

The relationship between the preferred land use and the current land use pattern is shown in Figure 2 .

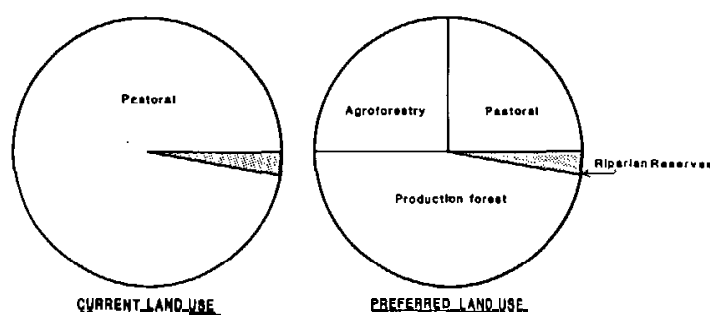

Figure 2 Kahika Block - current and preferred land use.

The long term economic and commercial viability of the preferred land uses was assessed using conventional cost-benefit analysis and discount rates of $7 \%, 10 \%$ and $12 \%$. It is accepted that the discount rates used are very high from a real rate point of view (particularly in the $10 \%$ to $12 \%$ range). The $7 \%$ is justifiable in the current economic environment in New Zealand, with this rate being currently demanded by most investors over and above the annualised rate of inflation. The long term nature of the investment (particularly forestry) also requires that a marginally higher real discount rate be used than may be the case with alternative shorter term and less risky investment opportunities. In recognition of these factors, a second phase study associated with determining the actual costs involved with facilitating the land use change will be undertaken. In this study a more acceptable real discount range of $4 \%, 7 \%$ and $10 \%$ will be used. The higher rate of $10 \%$ is the base discount rate usually required by New Zealand Treasury in the initial analysis of public funded or subsidised capital works, and will be included in order that this benchmark analysis is available if required.

As part of the cost benefit analysis a comparative analysis was undertaken in order to compare the economic and commercial viability of the preferred land use with a range of scenarios including:

(a) Analysis without any change to land use patterns;

(b) Alternative financing methods for the agroforestry land use including prolonged spreads of planting overtime, joint ventures and borrowing;

(c) Partial adaption of recommended land uses, with a $50 \%-100 \%$ proportion of the proposed agro-forestry area being retired to native reserve.

Continued pastoral farming was found to be more economic, in net present value terms, than any of the proposed changes. However, continued pastoral use of much of the area is physically not sustainable in the long term, and is economic only by virtue of a 
rundown low input operation which also yields up capital, as stocking rate and hence numbers fall away.

The net present value, at the discount rates of $7 \%$, $10 \%$ and $12 \%$ of the preferred land use options tested, improved as the agroforestry planting spread was increased. This was seen as a factor of prolonged livestock grazing income accruing prior to forest planting, and the postponement of high forestry development costs

None of the pastoral agroforestry scenarios tested was shown to be commercially viable in cash flow terms if funded from cash farm surplus or by borrowing. To overcome this a joint venture approach with agroforestry planting spreads of at least 10 years was recommended.

The net present values for the low cost retirement scenarios were in all cases lower than for the equivalent pastoral/agroforestry regimes.

Based on the Kahika Study concept the extent of change required over the total 65000 ha identified as needing reorganisation is shown in Table 2 . This degree of change would reduce the number of pastoral units from the current 175 to around 100.

Table 2 Recommended revised land use

Esk/Mohaka Study Block

\begin{tabular}{lrr}
\hline & Area & Percentage \\
\hline Pastoral & 27000 ha & 42 \\
Agroforestry & 17000 ha & 26 \\
Woodlot forestry & 19000 ha & 29 \\
Reserves & 2000 ha & 3 \\
& 65000 ha & 1000 \\
\hline
\end{tabular}

\section{A MECHANISM OF CHANGE}

A major question arising from the Kahiia Study is how to change land use patterns from their existing state to a preferred situation. The options for doing this fall into three categories: market forces, incentives and regulations.

Market forces on their own are unlikely to result in preferred land use changes, because no one decision-maker faces a complete set of costs and benefits. To overcome this an incentive designed to align private and social net benefits is required.

Regulations are not considered a viable mechanism of assisting land use change.

A portion of the costs of change can and should be met from commercial sources through a range of mechanisms which encourage, for example, direct investment and joint venture arrangements.

There is, however, a non-commercial cost of both facilitating and achieving the changes in land use. This cost arises from the combination of overcapitalisation of existing holdings, legal and survey fees and the possible difference between the current market values and the lower perceived productive values based on the new land uses which involve afforestation. Investors require a minimum real rate of return, and the capital value they place on the land and buildings particularly for forestry purposes will be lower than the current market values if based on their rate of return expectations. In this respect the investment value of the land and buildings will vary, depending on investor expectations.

Effective land use change and farm restructuring is unlikely to occur without a facilitator of change and a source of funding of the non-commercial costs of change. The main source of funding of this noncommercial component has to be addressed, but is likely to include agencies of Central Government, as the national representative of the community as a whole, and Regional Government.

Not withstanding the theoretical arguments against Government financial intervention to support the process of change, there are two arguments in favour of Government assistance. The first is that, from the perspective of practical politics, such an intervention can be seen as minimising the extent to which Government will be called on to meet the costs arising from future adverse climatic events. Secondly, by changing to a forestry land use, the employment opportunity within the region is enhanced. Forestry, including transport and processing at final harvest, is more labour intensive than pastoral farming, and will provide real benefits for employment in a region with high unemployment. This will reduce the long term dependence on the Government welfare system and the taxpayer in general, and is a strong argument for Government accepting at least some part of the cost change.

It can also be argued that Government indeed has a moral obligation. This relates to past production incentives which, applied to the pastoral industry nationally, resulted in a change of land use in the region from protected land to unsustainable pastoral land use. Thus, some of the costs of returning the land to sustainable and protected long term use should be borne by Government.

The scheme adopted for change in Hawke's Bay is likely to be a mixture encompassing free market philosophies and incentives. A suggested sequence is listed below:

\section{Scheme advertising}

Existing landowners advise of willingness to participate in scheme

* Scheme conditions advised

- Land use conditions listed in tender documents (i.e. timing of implementation, up front costs, environmental constraints)

- Preferential buying rights of existing landowners established

- Procedures for acceptance or rejection of tender and arbitration procedures established

- Penalty clauses for rejection of purchase offers established (i.e. no adverse event assistance for 10 years) 
* Area accurately mapped according to recommended land use and new boundaries applied.

* Areas valued and overcapitalised assets identified

* New blocks advertised (internationally) on the basis of invitation to tender for purchase thereof.

* Tenders accepted/rejected.

* Facilitating cost met by Central and Regional Government (i.e., legal/survey cost and overcapitalised cost)

\section{CONCLUSION}

Effective farm restructuring and sustainable land use patterns in northern Hawke's bay will not be achieved without some form of external facilitation and funding. Land use change of the scale suggested is likely to have significant commercial and noncommercial components. While free market mechanisms will be sufficient to facilitate a change with a commercial component, incentives are required for the noncommercial components.
Acknowledgements This paper is based on a project in the Tutira district in which a number of people have been involved. In particularly I.H. Cairns (H.B.C.B.); I. McIntosh (M.A.F.); J.A. Hayward (Centre for Resource Management); P. McKinley (Centre for Community Initiatives); and P.H.B Aldwell (Forest Research Institute). The assistance of all of these people with the project is acknowledged.

In addition the supportive role of landowners, particularly in the Kahika Block, is acknowledged. Without their support and assistance the project could not have proceeded.

\section{REFERENCES}

De Rose, R.C.; Trustrum, N.A. 1988. Geomorphology 1: 143-160. Douglas, G.B.; Trustrum, N.A.; Brown, I.C. 1986. NZ Journal of Agricultural Research 2: 183-192.

Guthrie-Smith, H. 1953. Tutira, Williams Blackwood \& Son Ltd. Haywick, D.W.; Lowe, D.A.; Beu, A.G. 1989. NZ Journal of Geology \& Geophysics (In Press)

Ministry of Works \& Development 1974 NZ Land Resource Inventory Worksheets, Northern Hawke's Bay legend. 